\title{
Nogami na ziemi. Rola ciała w etnografii przedtekstowej
}

Anne Line Dalsgård

TEKSTY DRUGIE 2018, NR 1, S. 154-172

DOI: $10.18318 /$ td.2018.1.9

Nie ma to nic wspólnego z wiedzą tajemną ani ezoteryką, nawet jeśli rzecz jest trudna, „sprzeczna z naturą”, jak mawiał Hegel, daleka od oczywistości, oraz wymaga pewnej pracy, a nawet ciężkiej roboty. ${ }^{1}$

Antropologia jest dyscypliną akademicką. W związku z tym poznanie i kategoryzowanie stanowią podstawę jej wysiłków. Antropologia może jednak być czymś więcej: dążeniem do zrozumienia, co znaczy być człowiekiem. Łączy się ono z rezygnacją z uznawanych pewników i samoograniczeń czy też z tego, co Husserl określał jako czyjeś „naturalne podejście”. Jeżeli jednak tym właśnie jest projekt, który nazywamy antropologią, to kluczowy element stanowi cielesność antropologa. Taką właśnie tezę tutaj stawiam.

1 N. Depraz The phenomenological reduction as praxis, w: The View from Within. First-person Approaches to the Study of Consciousness, ed. by F.J. Varela, J. Shear, Imprint Academic, Thorverton 1999, s. 109.

\footnotetext{
Anne Line Dalsgård

- profesor na

Wydziale Antropologii Uniwersytetu w Aarhus. Z wykształcenia aktorka, interesuje się cielesnymi i emocjonalnymi aspektami rozumienia oraz badaniami w zakresie antropologii fenomenologicznej. Od ponad 20 lat prowadzi badania w Brazylii. Autorka książki Matters of Life and Longing: Female Sterilisation in Northeast Brazil.
} 
Najpierw poddaję refleksji momenty przedtekstowego doświadczenia w badaniach terenowych. Stwierdzam, podobnie jak Edwin Ardener, że doświadczenie ucieleśnionej różnicy może stanowić moment transformacji. Następnie omawiam filozoficzne pojęcie epoché, rozumianej zarówno jako zdolność do „zawieszenia własnego pozbawionego uważności zanurzenia w doświadczeniu, jak i zwrócenie uwagi na sposób, w jaki coś się jawi, czy też dane jest doświadczeniu"2. Opisuję, w jaki sposób to zawieszenie pozbawionego uważności zanurzenia w doświadczeniu może zostać wywołane przez doświadczenie własnej fizycznej obecności i na odwrót. Po trzecie, wskazuję, że taka zdolność zawieszenia nie jest wrodzoną cechą człowieka, lecz stanowi umiejętność, której trzeba się nauczyć. Odwołuję się przy tym do własnych doświadczeń aktorskich, a przede wszystkim do treningu emocjonalnego, który przeszłam jako aktorka teatralna. Antropolożka w terenie, podobnie jak aktorka, używa własnego ciała jako podstawowego narzędzia pracy; jednak w odróżnieniu od aktorki antropolożka nieczęsto ma za sobą trening dający świadomość ciała. Uświadomienie sobie danych przedtekstowych wymaga, by najpierw uświadomić sobie w bezpośrednim doświadczeniu, co to znaczy być ciałem. Niektórym pomaga przypadek, ćwiczenie praktycznych umiejętności pomaga innym. Postuluję zatem poświęcenie większej uwagi świadomości ciała w edukacji początkujących antropologów.

\section{Spotkanie z ucieleśnionym Innym}

Choć antropologia zawsze zajmowała się Innością, ciągle w niej brak precyzyjnej definicji metody, która pozwala wyjść poza oczywistość „własnego domu” i zbliżyć się do tego, co nieznane. Antropolodzy nazywają tę metodę„,obserwacją uczestniczącą" i wielu z nas starało się zrozumieć i wyjaśnić, co miałaby oznaczać ta z pozoru sprzeczna nazwa. W czwartym wydaniu klasycznej już pracy Research Methods in Anthropology Russell Bernard pisze tak: „Obserwacja uczestnicząca łączy się z zanurzeniem się w jakiejś kulturze; trzeba się jednak nauczyć codziennego wynurzania, by poddawać intelektualnej analizie to, co się widziało i słyszało. [...] Prawidłowo prowadzona obserwacja uczestnicząca zmienia badacza terenowego w urządzenie do zbierania danych i ich analizy. [...] To rzemiosło"3.

2 E. Thompson Mind in Life. Biology, Phenomenology, and the Sciences of Mind, The Belknap Press of Harvard University Press, Cambridge, MA 2007, S. 19.

3 R. Bernard Research Methods in Anthropology: Qualitative and Quantitative Approaches, Altamira Press, Lanham-New York-Toronto-Oxford 2006, s. 344. 
Kirsten Hastrup opisuje obserwację uczestniczącą jako proces stawania się: „Stawanie się to metafora takiego rodzaju uczestnictwa, które nigdy nie będzie całkowite i które nie stanowi bezpośredniej konsekwencji fizycznej obecności [...] [człowiek] [n]ie zostaje zupełnie wchłonięty przez ten inny świat, lecz nie jest już także taki sam jak przedtem. [...] Obserwacja uczestnicząca dziś oznacza obserwację samego uczestnictwa"4. Carol Landerman ujmuje to jeszcze bardziej romantycznie i otwarcie: „Antropolodzy [...] uczestniczą na tyle, na ile się da, starając się jak najgłębiej wniknąć w życie swoich badanych, lecz zachowując równocześnie wystarczający dystans, by móc obserwować działanie kultury. Są w samym środku, a zarazem na zewnątrz, obserwując chłodnym okiem i uczestnicząc gorącym sercem"5. W tego rodzaju opisach często pojawia się nacisk na zmianę trybu od zanurzenia do wycofania lub równoczesność tych postaw. Czytamy też, a także piszemy, pełne emocji apologie obserwacji uczestniczącej, obwołując ją wyjątkową metodą badawczą, w której ciało badacza i jego zdrowy rozum mogą nawet zostać narażone na szwank. Bardzo niewiele jest jednak wyważonych, fenomenologicznych opisów prób stosowania tej metody w praktyce.

Tak zwana „antropologia zmysłów”, którą w latach 80. i 9o. XX wieku powołali do życia (między innymi) Steven Feld ${ }^{6}$ i Paul Stoller ${ }^{7}$, oraz podobnie znaczące prace Thomasa Csordasa ${ }^{8} \mathrm{i}$ Tima Ingolda9 o ucieleśnieniu i zamieszkiwaniu koncentrowały się na roli zarówno percepcji, jak i doświadczenia w ludzkim życiu, nie wyłączając profesji antropologa. Csordas i inni autorzy publikujący w tomie Embodiement and Experience ${ }^{\mathbf{1 0}}$, inspirując się m.in. dziełem Martina Heideggera i Maurice'a Merleau-Ponty'ego, pokazali do jakiego

4 K. Hastrup Droga do antropologii, przeł. E. Klekot, Wydawnictwo UJ, Kraków 2008, s. 31.

5 C. Landerman The embodiment of symbols and the acculturation of the anthropologist, w: Embodiment and Experience: The Existential Ground of Culture and Self, ed. by T. Csordas, Cambridge University Press, Cambridge 1994, S. 192.

6 S. Feld Sound and Sentiment, University of Pennsylvania Press, Philadelphia 1982.

7 P. Stoller The Taste of Ethnographic Things: The Senses in Ethnography, University of Pennsylvania Press, Philadelphia 1989.

8 T. Csordas Embodiment and Experience. The Existential Ground of Culture and Self, Cambridge University Press, Cambridge 1994.

9 T. Ingold The Perception of the Environment, Routledge, London 2000. 
stopnia znaczenia kulturowe są immanentnie wpisanie w ucieleśnione doświadczenie. Jednak podejście do wykorzystania doświadczenia w analizie było nadal dość prostoduszne. W artykule The embodiment of symbols and the acculturation of the anthropologist, zamieszczonym w tym właśnie tomie, Landerman wiernie opisała, w jaki sposób przejęła nawyki cielesne i umysłowe właściwe dla terenu badań, i że nie może być inaczej:

\begin{abstract}
Antropolodzy, którym udało się nawiązać relację, zauważają, że do pewnego stopnia ulegli akulturacji do wierzeń i zachowań swych informatorów. Oznaką tego procesu są zmiany w sposobie poruszania się i gestach, jak w moim wypadku, gdy zaczęłam kucać wśród Malajek, które przygotowują jedzenie w pozycji kucznej. Właściwie nie zdawałam sobie sprawy, że podczas tych czynności kucam, a nie siedzę przy stole, jak robiłam przez całe życie, dopóki mój mąż nie zauważył tego ze śmiechem, nazywając mnie swoją malajską żoną."
\end{abstract}

Landerman dochodzi do wniosku, że rzeczywistość empiryczna - „rzeczywistość naszych zmysłów"12 - zawsze jest już kulturowa: w ten sposób udaje się jej uniknąć pozornie naiwnego zlania się w jedno jej własnego rozumienia malajskiej symboliki z rozumieniem tej symboliki przez informatorów. Pod sam koniec artykułu wpada jednak w pułapkę przedstawienia struktury symbolicznej, która „pozwala zinterpretować doświadczenie” ${ }^{13}$, tak jakby doświadczenie było czymś poprzedzającym symboliczność. Koncepcja doświadczenia jako przedkulturowego to jedna z pułapek czyhających na antropologa o fenomenologicznym nastawieniu: Inny staje się naiwnym połączeniem dwóch wspomnianych przed chwilą światów, gdyż zamieszkiwanie świata Innego brane jest za doświadczanie świata Innego. Z tym właśnie mamy do czynienia w bardzo inspirującym artykule Grega Downinga ${ }^{14}$ o materialności muzyki: Downing pisze bowiem: „Bez uczestnictwa stwierdzenie w rodzaju «rytm wchodzi ci w krew» można uznać za metaforyczną hiperbolę i z łatwością zlekceważyć. Jednak dzięki fenomenologicznej redukcji to, co

11

C. Landerman The embodiment of symbols..., s. 192 [przekł. tłum].

Tamże, s. 196.

Tamże.

G. Downing Listening to capoeira: phenomenology, embodiment, and the materiality of music, "Ethnomusicology" 2002 No. 46 (3), s. 487-509. 
początkowo wydawało się kliszą, ujawnia się jako wymowne współdzielenie doświadczenia"15. Podczas gdy u Laderman doświadczenie poprzedza struktury symboliczne, Downing zakłada współdzielenie doświadczenia dzięki poddaniu się muzyce. Opisanie różnic kulturowych w percepcji wydaje się trudne, jeśli w ogóle nie niemożliwe, bez łączenia tych rzeczywistości w taki czy inny sposób, czyli albo w postaci percepcji przedsymbolicznej, albo w postaci podzielanego doświadczenia po przejęciu kultury badanych. Moje pytanie brzmi więc następująco: czy w istocie nie potrafimy zaakceptować różnicy jako doświadczanego faktu? A jeśli tak jest, to czy dzieje się tak dlatego, że nie potrafimy podtrzymać uwagi potrzebnej do takiego doświadczenia? Antropologia zawsze zmagała się z doświadczeniem różnicy: źródłem był wstrząs przy zetknięciu z nieuporządkowanym światem poza Europą; moim zdaniem nadal jednak nie wiemy, co z nim zrobić.

Niniejszy tekst odwołuje się do mojej własnej przeszłości, do dyskusji teoretycznych z lat 9o. XX wieku. Ciągle pamiętam, jak w 1998 roku Michael Jackson jako profesor antropologii przyjechał na gościnne wykłady do naszego instytutu w Kopenhadze . Był już wówczas szeroko znany z ważnych prac, inspirowanych fenomenologią, egzystencjalizmem i amerykańskim pragmatyzmem. Pewnego dnia, po wykładzie, który miał na seminarium dla pracowników instytutu, ktoś odważył się zapytać: ,jakich metod używa pan podczas badań terenowych?”. Po krótkim zastanowieniu Jackson odparł: „nazywam je osadzeniem”16. Grupa słuchaczy jakby się wzdrygnęła. „Osadzenie” to termin należący do innego pola wiedzy, z zakresu terapii i pracy z ciałem; i z pewnością nie było to coś, o czym antropolodzy chcieliby rozmawiać. A jednak poczułam, że dokładnie wiem, o co mu chodzi. Prawdopodobnie sama nie użyłabym terminu „osadzenie", lecz raczej może sformułowania „wewnętrzne poczucie własnego bycia w ciele". Mam świadomość, że to nie jest dokładnie to samo, ponieważ osadzenie podkreśla relację z podłożem, z ziemią. Jednak oba odnoszą się do włączenia własnego ciała w pole uwagi; a to - jak postaram się dalej pokazać - jest warunkiem każdego rozpoznania Inności.

Tamże, s. 504-505.

16 Oryg. grounding można przełożyć jako „ugruntowanie”, co budziłoby skojarzenia z teorią ugruntowaną (grounded theory) Straussa i Glasera - jednak autorka nie wskazuje na taki związek, a pisze o kontekście terapeutycznym, w którym po polsku pojawia się "osadzanie w ciele" [przyp. tłum.]. 


\section{Momenty rozumienia podczas badań terenowych}

O ile wiem, nikt $\mathrm{z}$ antropologów nie wymyślił lepszego słowa niż „osadzenie" ani jego definicji - co nie znaczy, że nie ma opisów chwil zrozumienia, w których „osadzenie" (rozumiane jako poczucie własnej umiejscowionej obecności) musiało być czynnikiem znaczącym. Chciałabym tutaj odwołać się do dwóch przykładów, które mnie szczególnie zainspirowały - jeden jest, jak sądzę, fikcją, drugi pochodzi z konkretnych badań terenowych.

Pierwszy pochodzi z artykułu Edwina Ardenera Comprehending others ${ }^{17}$. Pisząc o równoczesności języka i sfery materialnej, Ardener zastanawia się nad podaniem ręki w Anglii i u Ibo z południowo-wschodniej Nigerii. Angielskie słowo hand (dłoń) ${ }^{18}$ oznacza tę część górnej kończyny, która obejmuje to, co nazywamy palcami, i kończy w przegubie nadgarstka, natomiast w języku Ibo słowo aka obejmuje całą kończynę prawie po bark. Jak pisze Ardener:

W związku z tym uścisk samej dłoni, któremu towarzyszy poruszenie nią w nadgarstku, mógłby przywiązanemu do tradycji Ibo wydawać się nieco niezrozumiałym ograniczeniem ruchu, budzącym być może uczucia podobne do tych, które towarzyszą Anglikowi w sytuacji, gdy ktoś podaje mu dwa lub trzy palce. Jednak patrząc z perspektywy użytkownika angielskiego „podanie ręki" $\mathrm{i}$ „uścisk ramion” to dwa różne rodzaje pozdrowienia; dla Ibo to różne stopnie intensywności, ostentacji, serdeczności „tego samego" pozdrowienia. Wynika z tego, że nawet „serdeczne” wyciągnięcie ręki w sensie angielskim z perspektywy Ibo może wydawać się stosunkowo chłodnym pozdrowieniem. ${ }^{19}$

Jak pisze dalej Ardener, , albo nigdy nie dochodzi do porozumienia, albo jeśli zrozumie się tę różnicę, podanie ręki nigdy nie jest już tym samym"20. Rozumienie Innego łączy się ze zmianą własnej percepcji świata czy przynajmniej sposobu postrzegania ręki.

17 E. Ardener Comprehending others, w: Edwin Ardener. The Voice of Prophecy and Other Essays, ed. by M. Chapman, Basil Blackwell, Oxford 1989.

18 W polszczyźnie jest „podanie ręki", ale także "uścisk dłoni”, przy czym to pierwsze oznacza de facto to drugie; angielskie "shaking hand", które można tłumaczyć jako obie te formy, to dosłownie "potrząsanie dłonią". 
Drugi przykład pochodzi z książki Michaela Jacksona Paths Towards a Clearing ${ }^{21}$. Jackson przekonuje w niej do „osadzonego spojrzenia" na ludzkie życie, w którym rozumienie wyrasta $\mathrm{z}$ doświadczenia ciała, interakcji i wątpliwości, a nie z abstrakcji i sądów. Wśród różnych doświadczeń opisuje on m.in., w jaki sposób nauczył się rozpalać ogień, kiedy po raz pierwszy był u Kuranko w Sierra Leone.

„Układałem ognisko niestarannie i marnowałem mnóstwo drewna. Chodziło o to, żeby zrobić to szybko i zająć się rzeczami, które były moim zdaniem ważniejsze. [...] Jednak pewnego dnia zupełnie bez powodu przyjrzałem się jak kobiety Kuranko rozpalają ogień i go podsycają, i zacząłem naśladować ich technikę [...] Ta «praktyczna mimesis» pozwoliła mi zrozumieć, jak ludzie oszczędzają zarówno opał, jak i własną energię"22 .Za pomocą tego przykładu Jackson wskazuje, że zamieszkiwanie świata innych, „włączanie się w niego bez żadnych ukrytych motywów i dosłownie zajmowanie miejsca innych"23 może stać się źródłem niemal instynktownego zrozumienia innego życia, w chwili gdy się coś robi: „Uczestnictwo staje się więc raczej celem samym w sobie niż sposobem gromadzenia danych z obserwacji, które zostaną przeanalizowane gdzie indziej, już po tym wydarzeniu"24. Słowa i pojęcia dzielą i różnią, twierdzi Jackson, natomiast gesty i działanie stwarzają możliwość zamieszkiwania tego, co do tej pory było nieznane. Układanie ogniska na sposób Kuranko może wydawać się dziwaczne i zupełnie niepotrzebnie zagmatwane, lecz przez powtarzanie działań kobiet i naśladowanie sposobu, w jaki obchodzą się one z drewnem (nazywa to "rozniecaniem”), Jackson zdaje sobie sprawę z istnienia znaczeń leżących poza jego własnym horyzontem. Innymi słowy, za sprawą mimetycznego naśladowania intencji Innego intencje te same mogą objawić się niewtajemniczonemu.

W przykładzie Ardenera kategoria językowa dzieli oraz odróżnia postrzeganie ciała i jego używanie. Nierozpoznana różnica między słowami hand i aka rodzi nieporozumienie, prowadzące raczej do niezgodności niż wzajemności i zrozumienia; lecz rzeczywiste wzajemne dotykanie się górnymi kończynami może też łączyć się dla obu stron z cenną możliwością. Dla

M. Jackson Paths Towards a Clearing: Radical Empiricism and Ethnographic Inquiry, Indiana University Press, Bloomington 1989. 
Ardenera tym, co pozwala zrozumieć ten wspólny ludzki potencjał, jest nie empatia, lecz rodzaj oddzielenia uwagi. Dopóki będziemy uważać, że hand i aka są tym samym, człowiek posługujący się angielskim i ten, który mówi w Ibo, prawdopodobnie będą wykonywać tę samą czynność fizyczną bezrefleksyjnie; w chwili niespodziewanie chłodnego podania ręki jeden z nich zobaczy być może w Innym radykalną odmienność, człowieka, który mając taką samą cielesną postać, doświadcza jej i używa w sposób głęboko inny. Jak ujmuje to Ardener, „w rozumieniu [...] chodzi chyba raczej o nierówność niż o równanie"25. To, co uniwersalnie ludzkie, mieści się w zdolności obu stron do doświadczenia tej ucieleśnionej różnicy, nie w samym doświadczeniu posiadania takiego samego ciała. Podobnie jak Jackson, Ardener pokazuje, że celem współuczestnictwa w działaniu nie jest osiąnięcie empatii, choć rozpoznanie Ardenera nie dotyczy różnicy intencji, lecz różnicy ontologicznej (ręka nie jest po prostu ręką).

W obu wypadkach zdobyte rozumienie jest przede wszystkim poczuciem, że świat jest czymś więcej niż nasze własne doświadczenie świata. Takie poczucie wymaga pewnego rodzaju oddalenia - nie dystansu wpisanego w z góry przyjęte założenia i uprzedmiotowienie, ale oddalenia doświadczanego między własną podmiotową obecnością i intencją a obecnością Innego. Sięgnięcie do filozofii, a dokładniej do fenomenologii, oraz do nowszych badań nad świadomością może nam pomóc w bardziej precyzyjnym opisie tej różnicy.

\section{Epoché}

Edmund Husserl jako pierwszy uznał fenomenologię doświadczeń myślenia i poznawania za niezbędny krok ku szeroko zakrojonej teorii poznania. Uważał, że nasza wiedza o świecie ulega zniekształceniu ze względu na jego praktyczne wykorzystanie oraz przyjęte z góry koncepcje. W związku z tym wprowadził pojęcie redukcji fenomenologicznej i epoché jako zawieszenie postawy uznawania rzeczy za oczywiste, którą nazywał „nastawieniem naturalnym”. To zawieszenie obecnie uważa się za główną metodę fenomenologii. Redukcja i epoché to części funkcjonalnej całości ${ }^{26} \mathrm{i}$ mimo rozmaitych definicji filozoficznych i różnic między tymi dwoma pojęciami będę dalej za

E. Ardener Comprehending others, s. 183. 
pomocą terminu epoché określała tę całość. Jak twierdzi Dan Zahavi ${ }^{27}$, sam Husserl porównywał epoché do przejścia z rzeczywistości dwuwymiarowej do świata w trzech wymiarach, w którym podmiotowość jawi się sama przed sobą. W tym poszerzonym polu uwagi podmiot nie jest już całkowicie zaabsorbowany swym działaniem i kwestiami świata społecznego: „Nadal istnieje on przede mną [...] pozbawiony jakiejkolwiek rzeczywistej skuteczności, poza uzasadnieniem [...] nie jestem nim już zainteresowany, więc potrafię kontemplować go z oddalenia"28. Projekt Husserla miał charakter czysto teoretyczny, był poszukiwaniem czystej, niezniekształconej wiedzy. Jednak w projekt ten wpisany był dylemat, ponieważ Husserl twierdził, że świadomość zawsze jest spowita w intencjonalność, a więc zawsze już pochwycona przez świat. Jak zatem powinniśmy praktykować epoché?

W tym miejscu antropolog może sięgnąć do następcy Husserla, Martina Heideggera, który twierdził, że Husserl pozostał zbyt kartezjański. Nasza relacja z rzeczami - uważał Heidegger - nie jest związkiem z przedmiotami wiedzy czy poznania, lecz instrumentalnie traktowanymi narzędziami, rzeczami poręcznymi, podobnie jak my sami jesteśmy tym, co robimy, czego używamy, oczekujemy, unikamy - krótko mówiąc, tym, na czym nam zale$\dot{z}^{29}$. Troska o świat taki, jaki on jest, oznacza troskę o „świat poręczny”, świat działań praktycznych. Dla Heideggera rzeczy są tym, czym są w praktycznym użyciu. Na przykład, żeby naprawdę zobaczyć młotek, nie można go zmieniać z przedmiotu traktowanego narzędziowo w przedmiot percepcji (co zerwałoby sieć relacji kluczowych dla jego narzędziowej natury). Udaje się tego nie robić, gdy rzeczy nie udają się w odpowiedni sposób: kiedy to, co było przed chwilą poręczne albo poręczne być przestaje (np. zepsuty młotek), albo znika (czyli znajduje się całkowicie poza poręcznością); czy też, gdy coś staje na przeszkodzie naszej trosce i musimy skierować uwagę na to zatroskanie ${ }^{30}$. Jak pisze Heidegger: „Bezradność, z jaką stajemy wobec takiej sytuacji, odkrywa jako niepełny modus zatroskania bycie-już-tylko-obecnym czegoś poręcznego"31. Innymi słowy, kiedy nasze praktyczne działanie zostaje przerwane, ponieważ zawiodła nas rzecz o charakterze narzędziowym, nagle dostrze-

27 Tamże.

N. Depraz The phenomenological reduction..., s. 100-101.

M. Heidegger Bycie i czas, przeł. B. Baran, PWN, Warszawa 2004. 
gamy sieć związków, w której było osadzone to narzędziowe funkcjonowa$n^{32}{ }^{32}$. Kiedy więc Husserl dąży do oderwanej, zdystansowanej kontemplacji, to Heidegger w przykładzie z młotkiem koncentruje się na potencjalnym zrozumieniu wynikającym z uczestnictwa. Jednak antropologowi w terenie nie wystarcza to, co może się przypadkiem wydarzyć, gdy działanie zostaje przerwane, ponieważ coś zawiodło. Po pierwsze, trzeba, byśmy potrafili zaryzykować porażkę, czy też do niej doprowadzić; po drugie, powinniśmy umieć trwać w zdumieniu (w bezradności w kategoriach Heideggera), by zaakceptować to, co postrzegamy. To tutaj właśnie ciało powinno odegrać swoją rolę.

Epoché często uważano za własność umysłu dokonującego introspekcji; tymczasem jest ona raczej poddaną dyscyplinie praktyką, w której głównym czynnikiem jest nasza cielesność. Epoché ma charakter chwilowy i wymaga ciągłego dokonywania na nowo; działa niemal jak rodzaj wstrząsu, „gest ra-

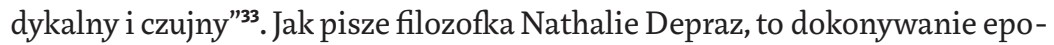
ché na nowo odbywa się poprzez „zanurzenie w ucieleśnionej wrażliwości,

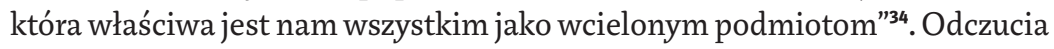
i afekt, mówi Depraz, nie są naszymi wrogami (jak chciał Kartezjusz), lecz sprzymierzeńcami w tej transformacji, a praktykowanie epoché sięga „w głąb naszej cielesności" ${ }^{35}$. Co to jednak dokładnie oznacza? Pewnej odpowiedzi udziela filozof Drew Leder w książce Absent Body. Być człowiekiem oznacza być miejscem intencjonalności, materialnie zdeterminowanej i wprowadzanej w życie ${ }^{36}$. W naszym ścieraniu się ze światem sięgamy po niego i naszym pierwotnym doświadczeniem nas samych jest "potrafię ${ }^{37}$. W tym ścieraniu się ze światem własne ucieleśnienie - nasza obecność jako „ciała i krwi”38 znika z pola uwagi. Leder mówi o dwóch rodzajach zniknięcia: o znikaniu w centrum, w którym ręka i młotek stają się jednym w intencji uderzenia w gwóźdź, a praca mięśni, krwi i nerwów jest poza naszym doświadczeniem;

H. Hall Intentionality and world: Division I of Being and Time, w: The Cambridge Companion to Heidegger, ed. by C.B. Guignon, Cambridge University Press, Cambridge 1993, s. 127.

N. Depraz The phenomenological reduction..., s. 101.

Tamże, s. 105.

Tamże, s. 107.

D. Leder The Absent Body, The University of Chicago Press, Chicago 1990, s. 124.

N. Depraz The phenomenological reduction..., s. 20; M. Merleau-Ponty Fenomenologia percepcji, przeł. M. Kowalska, J. Migasiński, Fundacja Aletheia Warszawa 2001, s. 175.

D. Leder The Absent Body, s. 66. 
oraz o znikaniu w tle, w którym reszta ciała pozostaje poza sferą uwagi, podczas gdy ręka pracuje młotkiem. Dopiero gdy ciało opadnie z sił i nie może wykonać tego, co zamierzaliśmy, uświadamiamy sobie jego obecność. Czy też przynajmniej tak żyjemy przez większość czasu. Leder przyznaje, że mamy „ciagle aktywne, choć działające podprogowo, schematy ciała i zmysł kinestetyczny, które ustawiają wszystkie nasze relacje ze światem" ${ }^{\text {39 }}$.To poczucie może stać się przedmiotem uwagi jako „ja jestem” czy też jako świadomość ciała tu i teraz ${ }^{40}$. Uwaga może zostać skierowana ku „ja jestem" w chwili zagrożenia, np. kiedy traci się fizyczną równowagę ${ }^{41}, \mathrm{w}$ doświadczeniu fizycznego bólu ${ }^{42}$, poprzez uświadomienie sobie innego ciała, np. przyjaciela, który idzie obok podczas pięknego dnia w lesie ${ }^{43}$, czy też wolicjonalnie, jak przy nauce nowych umiejętności czy przy medytacji ${ }^{44}$. Taka świadomość własnej fizycznej obecności jest moim zdaniem właśnie szokiem potrzebnym do ponownego dokonanie epoché.

W przeciwieństwie do solipsystycznego zwrotu ku własnej percepcji epoché zachodzi i za każdym razem dokonywana jest ponownie w interakcji z otaczającym światem. Wymiana słowna z innymi może być sposobem zerwania z przeświadczeniem o naturalności własnego postrzegania. Inny może też jednak wejść w odmienną rolę, bliższą mojemu „ja”, ,taką, z której rodzi się specyficzne poczucie obcości własnego ja [...] inny jest we mnie obecny w takiej postaci, która jest przewodnikiem w badaniu konkretnego doświadczenia"45. Depraz nie rozwija tematu „postaci, która jest przewodnikiem", ale Leder odwołuje się do podawanego przez Sartre'a przykładu podglądacza złapanego na gorącym uczynku przy dziurce od klucza ${ }^{46}$, widząc w nim fizyczną obecność, a zatem możliwość refleksji. Moim zdaniem jednak w przykładzie Sartre'a chodzi o samoświadomość jako publiczne „ja”, postrzegane tak, jak doświadczają go inni, a zatem jest to doświadczenie,

Tamże, s. 150.

Tamże, s. 19.

Tamże, s. 150.

Tamże, s. 70-79.

Tamże, s. 94 .

Tamże, s. 31, 153.

N. Depraz The phenomenological reduction..., s. 109.

D. Leder The Absent Body, s. 93. 
które oddziela podmiot od jego bytu doświadczającego w sposób niezapośredniczony ${ }^{47}$. Skutkiem bywa wstyd i lęk, a rzadko zainteresowanie sytuacją albo refleksja. Moim zdaniem jedynie w sytuacji, gdy spojrzenie Innego - czy to oceniające, czy zaskoczone - wywołuje poczucie obcości i zadziwienia, uprzedmiotowienie pomaga w zrozumieniu. Zatem do epoché potrzebna jest także pewna postawa podmiotu, różna od praktykowanej na co dzień, która oznacza uzależnienie człowieka od uznania własnej wartości przez innych. Depraz $\mathrm{w}$ artykule The phenomenological reduction as praxis $^{48}$ postuluje dalsze badania nad działaniem epoché w praktyce. Ona sama wraz z kilkorgiem innych badaczy starała się odpowiedzieć na ten postulat z perspektywy pola badań nad świadomością i uważnością ${ }^{49}$. Uważam, że antropologia proponuje kolejne pole praktyk, z którego może pochodzić odpowiedź. Podczas badań terenowych można celowo starać się zanurzyć w ucieleśnionej wrażliwości i doświadczać towarzyszącego temu szoku czy poczucia obcości, usiłując podczas interakcji z innymi ciągle zachowywać świadomość swego ciała. Można to nazwać postawieniem na głowie Heideggerowskiego doświadczenia z młotkiem: to nie zepsucie młotka przypadkowo wysuwa na pierwszy plan moją intencję i fizyczną obecność; przeciwnie, to doświadczanie własnej fizycznej obecności wysuwa na pierwszy plan młotek i moją intencję. To właśnie jest osadzenie, o którym mówił w mojej obecności Michael Jackson, i jest to sytuacja odmienna od filozoficznych eksperymentów z medytacją (a więc do nich komplementarna).

\section{Wyzwanie antropologii}

We Wprowadzeniu do fenomenologii Moran stwierdza, że „fenomenologia często była ukazywana przez krytyków jako odwoływanie się do od dawna już odrzuconych form introspekcji lub mistycznej, irracjonalnej intuicji, czy też propagowanie bezładnego poetyzowania o naturze doświadczenia przeżywanego" ${ }^{50}$. W antropologii fenomenologię często określa się (i czasem praktykuje) jako podejście nieteoretyczne, intuicyjne bycie-w-świecie,

47 N. Crossley Intersubjectivity. The Fabric of Social Becoming, Sage Publications, London 1996, s. 61.

48 N. Depraz The phenomenological reduction...

49 Por. np. N. Depraz, F. Varela, P. Vermersch On Becoming Aware: A Pragmatics of Experiencing, John Benjamins Publishing, Amsterdam 2003. 
w przeciwieństwie do analitycznych ambicji naukowych ${ }^{51}$. Nie o to jednak chodziło Husserlowi, Heideggerowi, Merleau-Ponty'emu i innym. Ich celem było stworzenie czysto teoretycznej metody, która pozwoliłaby na analizę każdej formy wiedzy, czy to naukowej, czy potocznych przekonań o świecie. Wiedza jest zawsze subiektywna - jak zatem, pytali twórcy fenomenologii, możemy poznać rzeczy takimi, jakie są w sensie obiektywnym? Chodzi o to, że to, czym one są, zawsze oznacza to, czym one są dla kogoś.

Kiedy pojęcie epoché trafia z filozofii do antropologii, przenosimy je ze sfery myśli w sferę działania, konkretnych spotkań i potencjalnie kłopotliwych nieporozumień. Jak pisał Bourdieu, ciało jest zamknięte w nieznanych konstrukcjach i jedyna nadzieja w antropologach, że zbadają autoreprezentacje i dyspozycje za pomocą „obiektywizacji uczestniczącej”52. Jak powinniśmy się do tego przygotować? W książce Doing Sensory Ethnography Sarah Pink ${ }^{53}$ ukazuje, jak samoświadome, refleksyjne wykorzystanie własnych zmysłów może stać się ważnym i znaczącym środkiem pojmowania i rozumienia doświadczenia innych ludzi. Pink odwołuje się do Davida Howe'a i Constance Classen, którzy sądzą, że badacze powinni wypracować refleksyjną ocenę własnych zdolności postrzegania zmysłowego, by „móc działać z pełną świadomością w systemach percepcyjnych dwóch porządków zmysłowych równocześnie (porządku zmysłowym własnej kultury i porządku zmysłowym kultury badanej), stale porównując notatki $i^{54}$. Sama Pink uznaje, że przygotowanie tego rodzaju pomogłoby nam rozbić doświadczenie na dane zmysłowe i pozwoliło zobaczyć nasze własne kategorie zmysłowe w działaniu, a być może dostrzec także ich ograniczenia ${ }^{55}$.

Pink stara się jednak dotrzeć do obszarów ucieleśnionej, umiejscowionej wiedzy, żeby zobaczyć to, co inni widzą, czuć zapachy, które oni czują, słyszeć to, co oni słyszą. Koncepcja „pełnej świadomości” i ciągłego robienia notatek ma taki sam cel: pragnienie, by wiedzieć i definiować. Istnieje też jednak, jak sądzę, cel skromniejszy - jest nim uznanie niemożności. Pink widzi to do

51 K. Hastrup Introduktion. Antropologiens vendinger, w: Viden om Verden: En Grundbog i Antropologisk Analyse, ed. by K. Hastrup, Hans Reitzels Forlag, København 2004, s. 17.

P. Bourdieu Zmysł praktyczny, przeł. M. Falski, Wydawnictwo UJ, Kraków 2008, s. 94. 
pewnego stopnia, gdy pisze, że „przy całej „wspólnocie” doświadczenia podobieństwo nie znaczy tożsamości"56. Dla mnie jednak nawet etnografia prowadzona w użyciem zmysłów zbyt łatwo przechodzi w kategorie i słowa. Zawsze jesteśmy "gdzieś konkretnie" " zawsze w takim czy innym świecie. Richard Shweder w książce Thinking Through Cultures proponuje, by zaakceptować niewspółmierność, jeśli się pojawia: „Ze względu na nasze ograniczenia, niespójność zachodząca między [dwoma przeciwstawnymi punktami widzenia] nie jest czymś, co wymaga od nas rozwiązania, lecz czymś, czego powinniśmy szukać, by zdziwienie sprawiało, że poruszając się między różnymi światami uzupełnimy braki" ${ }^{28}$. Jak mamy się przygotować, by nasza uwaga stała się wszechogarniająca? Aby doświadczenie „poruszania się między różnymi światami” stało się naszym udziałem, musimy w naszych stosunkach z rzeczywistością przeprowadzić separację czy też dokonać wewnętrznego oddzielenia, tak byśmy nie utożsamiali się już w pełni ani z jednym, ani z drugim światem (czy też, używając słów Thompsona, w żadnym z nich nie byli zanurzeni w sposób pozbawiony uważności). Jedynie takie oddzielenie, zrozumienie, że ręka niekoniecznie oznacza rękę, tak jak my ją rozumiemy, ponieważ nagle stajemy wobec dwóch niewspółmiernych znaczeń tego słowa, pozwoli na zmianę percepcji, na odnowienie naszego stosunku do świata - kiedy młotek nie jest już przedłużeniem mojej ręki, lecz gdy kierując uwagę na odczucia tej ręki, zdaję sobie sprawę, że trzymam młotek i chcę uderzyć w znajdujący się przede mną gwóźdź. To znaczy, że nie utożsamiam się już z wbijaniem młotka, nie jestem praktycznym działaniem, moim „potrafię", lecz jestem także na zewnątrz tego działania, zdolna do zrozumienia mojego „jestem”.

Możemy zapytać: dlaczego trzeba się wycofać z utożsamienia? Jaki cel ma obserwacja uczestnicząca, jeśli przybiera taką postać? Pisząc to, widzę siebie samą, jak stoję przed szpitalnym łóżkiem, na którym leży rodząca kobieta. Dzieje się to w Recife, mieście na biednym północnym wschodzie Brazylii, gdzie często prowadziłam badania terenowe. Kobieta ma brunatną skórę, a jej stopy naznaczone są biedą: szerokie, o skórze zgrubiałej od noszenia przez cały rok tanich gumowych sandałów. Personel medyczny wokół niej, ubrany w ładne, białe stroje, śmieje się i pogaduje, choć ich twarze są zasłonięte szpitalnymi maskami. Kobieta bardzo cierpi, lecz wydaje się, że nikt

56 Tamże, s. 77.

57 R. Shweder Thinking Through Cultures, Harvard University Press, Cambridge, MA 1991, s. 19.

58 Tamże. 
jej nie zauważa. Mój własny oddech, który czuję w masce, zmusza mnie do zdania sobie sprawy z tego, jak dziwaczna jest moja obecność w tej sali i jak tu jestem obca. Nie wiem, czy powinnam wziąć kobietę za rękę, czy wyjść; scena jest nie do zniesienia. Jednak poprzez dysonans intencji rozumiem, że rutynowo działający personel po prostu w płaczącej na łóżku istocie nie dostrzega bliźniego, drugiego człowieka. Ci ludzie zostali schwytani przez swe działania i - przywołując obraz, który zawdzięczamy Heideggerowi - żadna awaria ani błąd nie umożliwiły im dostrzeżenia sieci relacji i z góry przyjętych osądów, w których jest osadzone ich funkcjonowanie. Ja, antropolożka, także jestem schwytana w nastawienie i myślenie wynikające $\mathrm{z}$ rutyny i wzbiera we mnie litość dla kobiety oraz silne poczucie niesprawiedliwości. Lecz, czując pod nogami ziemię i własny oddech w masce, widzę coś więcej: perspektywy, które się przecinają i nigdy nie spotykają; wielką siłę przyzwyczajenia i utożsamienia; wysiłek, jakiego wymaga oddalenie się na chwilę od własnych przedsądów. Jest w tej wizji coś uniwersalnie prawdziwego, właśnie to, czego zawsze uczyła nas fenomenologia: nikt nie może istnieć w kulturowej pustce i każdy jest uwikłany w troski i niepokoje o charakterze społecznym. Kategorie kulturowe i hierarchie społeczne, w których żyjemy i spotykamy się ze sobą, oznaczają brak rzeczywistego miejsca spotkania. Dostrzeżenie tego braku to być może najbliżej, jak uda nam się posunąć w zrozumieniu zaniedbania czy nawet przemocy. To źródło swego rodzaju krytyki czy też antropologicznego raison d'être, które różnią się od oburzenia, zarówno w tonie, jak i, jeśli chodzi o skutki - wezwanie do kontemplacji59.

Istnieje wiele powodów, dla których prowadzi się antropologiczne badania terenowe. W moich własnych, dotyczących porodów i sterylizacji w Brazylii, ważne było zbadanie warunków i nadużyć, które skłaniały wiele kobiet do wyboru sterylizacji - interwencji chirurgicznej, która ma działanie głębsze i bardziej nieodwracalne niż większość z nich sobie wyobrażała i co do której wiele z nich najprawdopodobniej podjęłoby odmienną decyzję, gdyby miały inne możliwości. Wiele danych, które wytwarzamy jako antropolodzy, można zinstrumentalizować i zastosować przy poszukiwaniu lepszych praktyk, które mogą być ich szczęśliwym skutkiem, jeśli uda się je wprowadzić. Musimy jednak przyznać, że wiele dobrych intencji doprowadziło do absurdów ${ }^{60}$,

59 A.L. Dalsgård Sandalfødder og muligheden for forandring, "Tidsskrift for Antropologi" 2003 Vol. 45, s. 73-80.

60 N.H. Vohnsen Absurdity and the Sensible Decision: Implementation of Danish Labour Market Policy, Ph.D. thesis, Faculty of Arts, Aarhus University, Aarhus 2011. 
ponieważ działamy zdeterminowani przez nasze zawężające perspektywę przedsądy. Najważniejszym wkładem antropologii powinna zatem być walka o uzyskanie i przedstawienie pełniejszego obrazu sytuacji; takiego, w którym poglądy podmiotów są, jeśli nie szanowane, to przynajmniej rozumiane.

\section{Doświadczenie internalizacji}

Można sobie wyobrazić wiele różnych sposobów zastosowania epoché w praktyce antropologicznej (a właściwie w każdym praktycznym przedsięwzięciu). Trudniej natomiast je zrealizować. Wymaga to nie tylko swego rodzaju intelektualnej ciekawości i odwagi, jako że trzeba chcieć pozbyć się przedsądów; wymaga to też spokojnej uwagi, która potrafi objąć zarówno własne doświadczenie, jak i istnienie świata Innych. By było to możliwe, antropolog musi zawiesić, przynajmniej chwilowo, podstawę swej pewności i zakwestionować własne postrzeganie, pozwalając by Inność je podważyła. Musi on też umieć obserwować proces kwestionowania, cały czas koncentrując uwagę, co nie jest łatwe, jak wie każdy, kto tego próbował (postaraj się np. czuć swoje stopy, gdy idziesz - łatwo uświadomisz sobie, jak szybko uwaga się rozprasza i człowiek zapomina, co miał robić). Te wymagania cały czas brzmią jednak dość ogólnie i niejasno. Jak można by je bardziej uszczegółowić?

Można próbować, jak aktor teatralny, ćwiczyć uwagę i świadomość ciała, by wypracować zdolności, których nie używa się w grze, lecz w obserwacji uczestniczącej, która w istocie nie różni się tak bardzo od procesu uczenia się roli przez aktora. Kiedy aktor pracuje nad postacią, uczy się roli, dociera do Innego, którego zna tylko ze słów, z jego własnych wypowiedzi w sztuce lub tego, co mówią o nim inne jej postaci. Aktor musi sobie wyobrazić powody, dla których jego postać postępuje tak, jak postępuje, i próbować pojąć jej intencje, podążając za wskazaniami zawartymi w didaskaliach, tak jak robił Jackson, starając się ułożyć ognisko na sposób Kuranko. Postać wychodzi przez drzwi, ale czemu? Czy tę kwestię należy wypowiedzieć szeptem czy wykrzyczeć? Co będzie, jeśli stanę w tej scenie blisko niej? Aktor uczy się obserwować wyniki swych eksperymentów. W pewnej chwili to rola zaczyna grać aktorem, który - jak Laderman siedząca w kucki niczym Malajka - przestaje czuć, że jest gdzieś między „ja” i Innym, a zaczyna zamieszkiwać nowe istnienie. Dla antropologa najbardziej interesująca jest sytuacja pomiędzy, kiedy można obserwować oba światy. Sama inspirowałam się w pracy tym, czego nauczyłam się, należąc w latach 8o. XX wieku do młodego i prężnego zespołu teatralnego, działającego w Kopenhadze. Nasz chilijski reżyser, 
Horacio Muñoz, brał udział w naukowym projekcie badawczym kierowanym przez dr Susanę Bloch z Instytutu Neuronauk na Uniwersytecie Pierre'a i Marii Curie w Paryżu. Często uczestniczyliśmy jako badani w różnego rodzaju doświadczeniach, które ostatecznie doprowadziły do rozwoju konkretnej techniki o nazwie Alba Emoting.

Pamiętam, jak leżałam na podłodze w teatralnej sali prób, starając się na polecenie badacza oddychać w określony sposób - krótki, gwałtowny wdech przez nos i szybki wydech ustami, jak przy spółgłosce wybuchowej - kiedy powiedziano nam, byśmy delikatnie rozciągnęli wargi. „Poruszajcie się, rozluźnijcie ciało, nie przestając oddychać w ten sposób" - usłyszeliśmy; i nie minęła chwila, kiedy pierwsza osoba zaczęła się śmiać. Śmiech doświadczany wtedy tam, podczas leżenia na podłodze, był prawdziwy w tym sensie, że wprawiał nasze ciała w wibracje i napełniał nas radością; równocześnie nie był naszym własnym śmiechem, gdyż wynikał z instrukcji dr Bloch. Moje ciało zareagowało jednak na radosny śmiech w sposób niespodziewany: zaczęłam płakać, lecz tym razem nie było to na polecenie, lecz jak się wydawało, na skutek jakiegoś osobistego cierpienia. Zmienił się mój oddech i przez chwilę zaniosłam się szlochem, wciągając nosem powietrze w niewielkich porcjach, a wypuszczając je w całości w jednym długim wydechu. Zakłopotana sytuacją, rozluźniłam się, starając oddychać równo i regularnie - i niespodziewane emocje opadły. Emocjonalna mieszanka, dotyk podłogi i uświadomienie sobie, że mogę poruszać się w moim wewnętrznym krajobrazie uczuciowym za pomocą określonych sposobów oddychania, dały mi poczucie istnienia, napełniając zarazem zdumieniem. Odczuwałam przede wszystkim własną obecność w sali, swój ciężar na podłodze, ludzi wokół, rozwibrowaną, płynną materialność, której byłam częścią.

Przez następne lata pracowałam z tą techniką w różnych okolicznościach (ćwiczenia aktorskie, badania w laboratorium w Paryżu, konstruowanie roli do spektaklu, jako pejzaż dźwiękowy do przedstawienia), ale nigdy nie udało mi się w pełni opanować Alba Emoting. Mimo to zinternalizowałam alfabet emocjonalny, którego uczy ta technika. Isabel Santelices, młoda aktorka, która uczyła się tej techniki w szkole teatralnej na Uniwersytecie Chilijskim, tak opisuje jej internalizację: „, nawet bez zdawania sobie z tego sprawy, człowiek zaczyna inaczej «czytać» życie, teatr, fotografię itd., zawsze obserwując wszystko i porównując pod wpływem tej nowej wiedzy"61. Jednak, jako

61 S. Bloch The Alba of Emotions. Managing emotions through breathing, Ediciones Ultramarinos, Santiago 2006, s. 172. 
że nie ma ani naukowej, ani potocznej zgody co do zestawu podstawowych emocji, których używa ta technika (gniew, smutek, radość, czułość, erotyzm) w postaci czystej lub wymieszanych, mam pełną świadomość, że ten alfabet to tylko jedna z wielu możliwości. Nic nie poradzę na to, że widzę świat przez jego pryzmat, wiedząc równocześnie, że jest wyuczony. Zarówno zdumienie doświadczone na podłodze podczas ćwiczeń, jak i świadomość, że zinternalizowałam konkretny zestaw kategorii należących do tej, a nie innej techniki są dla antropolożki ważną nauką. Liczy się nie tyle umiejętność robienia czegoś, lecz raczej spojrzenie uzyskane dzięki ćwiczeniom.

\section{Przedtekstowość}

Czy doświadczenie może mieć charakter przedtekstowy, jeśli przyjmujemy, że nasze postrzeżenia są zawsze kulturowe? Oczywiście zależy, o co nam chodzi. Niewątpliwie moje doświadczenie na podłodze teatru nie było werbalne; $\mathrm{w}$ istocie pierwsze wrażenie sugerowało mi, że nie mam słów, by tę sytuację opisać. Nie wiedziałam, co się dzieje. Jeśli zatem przyjąć perspektywę czasową, to moje doświadczenie było przedtekstowe, gdyż dopiero później udało mi się opisać to, co się wydarzyło. Także przykład z ręką/aka jest doświadczeniem przedtekstowym w tym sensie, że Ardener opisuje sytuację, w której słowa także stają się przedmiotem doświadczenia, a ich rola nie ogranicza się do bycia medium, za pomocą którego można czegoś doświadczać. Można jednak także powiedzieć, że przytoczone przykłady dotyczą sytuacji ponadtekstowej, ponieważ zrozumienie dokonuje się ponad słowami ${ }^{62}$. W tych przykładach słowa niemal przeszkadzają. Jak w przykładzie Jacksona z ogniskiem, który każe nam podejrzewać, że nawet słowo „rozniecanie” staje na drodze do zrozumienia przez niego intencji kobiet. Wydaje się, że tym, czego potrzeba, żeby zrozumieć Innego, jest porzucenie nawet własnego słownictwa i własnych kategorii werbalnych, tak integralnie wpisanych w doświadczenie, że dają nam poczucie kontroli; trzeba bardziej nie-wiedzieć niż wiedzieć. Czy to możliwe, by jedyną rzeczą, która nam do tego potrzebna, było poczucie, że stoimy nogami na ziemi? Tak sądzę. A przynajmniej bylibyśmy znacznie bliżej tego zrozumienia.

Przełożyła Ewa Klekot

62 U. Wikan Beyond the words. the power of resonance, "American Ethnologist” 1992 No. 19 (3), s. 460-482. 


\section{Abstract}

\section{Anne Line Dalsgård}

AARHUS UNIVERSITY

Feet on the Ground: The Role of the Body in Pretextual Ethnography

In this article Dalsgård reflects upon moments of pretextual experience in fieldwork, comparing them with the philosophical notion of the epoché and discussing the methodological problems hereof on a theoretical level. She also proposes a way of working with aspects of this challenge with anthropology students as part of preparation for fieldwork. Dalsgård argues that to be aware of pretextual data, anthropologists need first to understand, by way of direct experience, what it means to be a body. Like the theatre actor, an anthropologist at fieldwork draws on her own body as her primary tool, but unlike the actor, the anthropologist often has not trained her bodily awareness. Drawing on Merleau-Ponty and contemporary phenomenologists (Zahavi, Depraz), as well as anthropologists like Michael Jackson and Robert Desjarlais, Dalsgård develops an argument in line with some of the most recent literature on creativity and design processes. Along the way she draws on her own experiences from playing in theatre and from her fieldwork in the north-east of Brazil.

\section{Keywords}

pretextual experience, fieldwork, epoché, body 